\title{
THE PERVERSE CONSEQUENCES OF ELECTORAL REFORM IN THE UNITED STATES
}

\author{
ADAM J. BERINSKY \\ Massachusetts Institute of Technology
}

\begin{abstract}
A number of electoral reforms have been enacted in the United States in the past three decades that are designed to increase turnout by easing restrictions on the casting of ballots. Both proponents and opponents of electoral reforms agree that these reforms should increase the demographic representativeness of the electorate by reducing the direct costs of voting, thereby increasing turnout among less-privileged groups who, presumably, are most sensitive to the costs of coming to the polls. In fact, these reforms have been greatly contested because both major political parties believe that increasing turnout among less-privileged groups will benefit Democratic politicians. I review evidence from numerous studies of electoral reform to demonstrate that reforms designed to make it easier for registered voters to cast their ballots actually increase, rather than reduce, socioeconomic biases in the composition of the voting public. I conclude with a recommendation that we shift the focus of electoral reform from an emphasis on institutional changes to a concentration on political engagement.
\end{abstract}

Keywords: election reform; voting; political participation; turnout; representation

In the past three decades, a series of electoral reforms have been enacted that are designed to increase turnout by easing restrictions on the casting of ballots, including voting-by-mail (VBM), early voting, the relaxing of stringent absentee balloting procedures, and Internet voting. Both proponents and opponents of electoral reforms agree that these reforms should increase the demographic representativeness of the electorate by reducing the direct costs of voting, thereby increasing turnout among groups of lower socioeconomic status who, pre-

Author's Note: This article draws heavily upon joint work with Nancy Burns and Mike Traugott. They are equally responsible for the development of the two-path conception of turnout discussed here but are innocent of any errors in this article. For comments on earlier drafts of this article, I would like to thank Jason Barabas, Jamie Druckman, James Gimpel, Ben Highton, Jennifer Jerit, Gabriel Lenz, Andrew Reeves, and Sarah Sled. I would also like to thank Michael Hanmer for providing access to his recoded CPS data and James McGhee and Alice Savage for research assistance.

AMERICAN POLITICS RESEARCH, Vol. 33 No. 4, July 2005 471-491

DOI: $10.1177 / 1532673 X 04269419$

(C) 2005 Sage Publications 
sumably, are most sensitive to the costs of coming to the polls. A more demographically diverse and representative electorate may have important implications for the American political system. ${ }^{1}$ Electoral reforms have, in fact, been greatly contested because both major political parties believe that increasing turnout among less-privileged groups will benefit Democratic politicians. However, contrary to expectations, the wave of electoral reforms may have increased turnout slightly but has not had the hypothesized partisan effects.

Electoral reforms, nevertheless, have had a significant, if unintended, effect. Most politicians and scholars have focused reform efforts on the tangible barriers to voting. These reforms are designed to lower or erase the barriers to voting, making it easier for all citizens to vote, regardless of their personal circumstances. However, the direct costs of registration and getting to the ballot box are only part of the picture. The more significant costs are the cognitive costs of becoming engaged with and informed about the political world. Political interest and engagement, after all, determine to a large extent who votes and who does not. Because levels of political engagement currently follow, rather than cross, demographic divisions in the electorate, reforms designed to make voting "easier" magnify the existing socioeconomic biases in the composition of the electorate. These reforms ensure that those citizens who are most engaged with the political world - those with politically relevant resources-continue to participate, whereas those individuals without such resources fall by the wayside. ${ }^{2}$

In this essay, I review evidence from numerous studies of electoral practices to demonstrate that reforms designed to make it easier for registered voters to cast their ballots increase, rather than reduce, socioeconomic biases in the composition of the voting public. ${ }^{3}$ This article discusses only those reforms that make it easier to vote once registered. Admittedly, the registration of voters is a critical step in the voting process. But, as I discuss in greater detail in what follows, many of the arguments made here concerning the act of voting can also be applied to the study of voter registration (Traugott, 2004; see also Highton [2004] for a detailed discussion of the effects of easing registration requirements).

I begin by advancing a two-process dynamic conception of the electorate. When discussing voting reforms, politicians and academ- 
ics often concentrate on encouraging — or "stimulating" new voters to join the electorate. However, stimulation only tells half the story. We must also consider the retention of voters from election to election. Using the stimulation/retention framework, I argue that reforms designed to make the act of voting easier increase the socioeconomic bias of the electorate. Rather than stimulating the unengaged, who are relatively deficient in political and economic resources, these reforms retain engaged voters - those who are rich in politically relevant resources. Thus, although electoral reforms may increase turnout, they do so by ensuring that politically engaged voters continue to come to polls election after election. I end with a call to refocus the study of voting - and political participation more generally-away from an examination of the direct costs of the act of voting to a study of the less perceptible, but equally important, costs of political engagement. Institutional change alone will not bring about a democratic electorate. No matter how low the direct costs to casting a ballot are set, the only way to accomplish both goals of increasing turnout and eliminating socioeconomic biases in the voting population is to increase the engagement of the broader mass public with the political world. Political information and interest, not the high tangible costs of the act of voting, are the real barriers to a truly democratic voting public.

\section{ELECTORAL REFORMS}

This review focuses on four particular reforms designed to ease the act of voting for citizens registered to vote in a given jurisdiction: permissive absentee balloting, early voting, VBM, and Internet voting. ${ }^{4}$ describe these reforms in turn here.

\section{PERMISSIVE ABSENTEE BALLOTING}

Many states restrict the use of absentee ballots to those citizens who cannot make it to the polls on Election Day because of occupation, business, studies, travel, or other reasons. However, other states have liberalized the use of absentee ballots. Altogether 22 states now make an absentee ballot available to any registered voter who requests one, 
without need to show cause (Hansen, 2001). ${ }^{5}$ Absentee balloting has become extremely popular in these states. For example, in the past two elections in California (the 2002 general election and the 2003 gubernatorial election), more than $25 \%$ of voters cast their votes through absentee ballots.

\section{EARLY VOTING}

Since 1988, voters in Texas and 13 other states have been permitted to cast ballots, in person, up to 3 weeks before the election at designated poling sites (Hansen, 2001; Stein, 1998). ${ }^{6}$ As is the case with permissive absentee balloting, voters do not have to establish prior cause to cast early ballots. Balloting sites are often placed in convenient places, such as supermarkets and post offices. In addition, in certain states-such as Texas - citizens do not have to vote in their own precinct. Instead, they can vote at any early voting site they find convenient. Like absentee balloting, early voting is used widely, when available. In 2000, for instance, $39 \%$ of the presidential vote in Texas was cast early (Hansen, 2001).

\section{VOTING-BY-MAIL}

Under VBM systems, every registered voter in a given jurisdiction receives a ballot that they can drop off or mail back to the proper election official. By mailing ballots to the homes of every registered voter up to 3 weeks in advance of Election Day, election officials give potential voters ample time to cast their votes at their convenience. VBM elections began at the local level in the late 1970s and have grown increasingly popular. By one estimate, 19 states have used VBM for at least one election and, since 1998, Oregon has conducted all its elections by mail (Berinsky, Burns, \& Traugott, 2001).

\section{INTERNET VOTING}

Internet voting is a voting system that would enable voters to cast a secure and secret ballot over the Internet. These ballots could be cast at computers placed at traditional polling places, designated Internet kiosks under the control of election officials, or from citizens' own 
homes-what Alvarez and Hall (2004) call "remote internet voting." Internet voting has not been adopted in any voting jurisdiction in the United States, but proponents of this method point to its promise in easing the costs of voting, especially for military personnel and the disabled (Alvarez \& Hall, 2004).

\section{THE DYNAMICS OF THE VOTING PROCESS}

To begin an examination of the effects of electoral laws on registered voters, we must start with a model of the electorate. One common conception of the electorate, advanced most explicitly by Campbell (1966) is that of a potentially expanding series of concentric circles. Campbell makes a distinction between a hard "core" of voters who always turn out, regardless of the particulars of an election, and sets of "peripheral" voters who participate only in high stakes elections. As Campbell argues, "The turnout in any specific election is largely a question of how many of the less interested, less responsive people, are sufficiently stimulated by the political circumstances of the moment to make the effort to vote" $\left(1966\right.$, p. 43). ${ }^{7}$ From this point of view, the way to expand the electorate is to somehow compel groups of peripheral voters to turn out.

Such a view of the electorate rests on the assumption that "peripheral voters" are the most likely to change their voting behavior from election to election, thereby driving the change in aggregate turnout levels. Under this view, only the "core" electorate votes in low-stimulus elections, such as local elections. As the electoral environment becomes more charged, as it does for close races and elections for national office, the voting population expands outward from the core, bringing in groups of increasingly apathetic voters from the periphery (Sigelman \& Jewell, 1986).

Citizens are not, however, so easily sorted into "core" and "peripheral" voters. ${ }^{8}$ Certainly some individuals vote in every election, and some individuals never vote, but many citizens sometimes cast a vote and sometimes do not. Turnout ebbs and flows as the characteristics of elections change; for instance, many more citizens vote in statewide elections than school board elections. Moreover, the volatility of indi- 
vidual turnout from election to election-changes which in the aggregate result in a churning of the electorate-is relatively high even between high intensity elections, such as Presidential elections. ${ }^{9}$ Focusing on aggregate turnout from election to election obscures the volatility in individual-level turnout behavior. Analysis of the voting behavior of individuals over time demonstrates that the movement of citizens in and out of the electorate does not conform to a view of electorate as composed of "peripheral" voters who join the "core" voters only in high-stimulus elections. Sigelman and Jewell (1986) examined the turnout patterns of registered voters over 10 elections in Kentucky from 1978 to 1982 and found tremendous volatility in individual voting behavior over that period. More recently, in a series of five elections in Oregon in the early 1990s, Berinsky, Burns, and Traugott (2001) found that the vast majority of registered voters, $65 \%$, were "transient voters" who moved in and out of the electorate over the election series. By comparison, 25\% were "constant voters" who turned out in all five elections, and only $10 \%$ were chronic "non-voters" who never cast a ballot, though they were eligible to do so. ${ }^{10}$

Taking a dynamic perspective of the electorate, we can see that stimulating new voters to join the ranks of the voting public is only one path to increasing the size of the electorate. Electoral reforms can also increase the size of the electorate over the long haul through retention-keeping those people who have voted in the past voting in the future, in low-intensity local elections as well as high-intensity presidential elections (Berinsky, Burns, \& Traugott, 2001; Traugott, 2004). ${ }^{11}$ Under this scenario, turnout may increase in the aggregate relative to the situation where reforms were not implemented because voters who previously turned out are transformed from "transient voters" to "constant voters," thereby reducing the movement of citizens out of the ranks of the voting public. Thus, not only will the composition of the electorate change but there will be a net increase in turnout. ${ }^{12}$

This two-path dynamic conception of turnout has consequences for the study of electoral reform. Scholars and politicians argue-either implicitly or explicitly - that electoral reforms that make voting easier will increase the size of the electorate, and that this increase will result from the stimulation of registered nonvoters. That is, they assume that electoral reforms will expand the "core" electorate out- 
ward to bring in new groups of "peripheral" voters. By lowering the direct costs of voting, these scholars assume that groups of individuals who are close to the threshold of participation will join the ranks of the constant voters. Such logic is incomplete. Electoral reforms may increase turnout through stimulation. However, electoral reforms also serve to retain transient voters from election to election, through both high intensity and low-intensity contests.

Distinguishing retention effects from stimulation effects is important because, if the stimulated voters and retained voters have different socioeconomic characteristics, these processes may affect the composition of the voting public in different ways. Specifically, the relative size and characteristics of these populations will determine the composition of the electorate. If these two groups differ in their personal characteristics, and these characteristics affect the ability of electoral reforms to change voting behavior, electoral reforms may have significant compositional effects. Thus, if we are concerned about the demographic representativeness of the electorate, we must see how the processes of stimulation and retention proceed, and pay attention to the characteristics and sizes of the groups of registered voters who are most likely to change their behavior in response to electoral reforms.

Here is where the perverse consequences of electoral reform take root. Both proponents and opponents of electoral reforms agree that these reforms would increase the demographic representativeness of the electorate by making it easier for citizens of low socioeconomic status to cast their ballot. That is, they believe that electoral reforms will stimulate the less well-off-who historically comprise "non-voters"- to join the electorate. ${ }^{13}$ These results do not, in fact, occur. Because the population of "transient" voters is endowed with greater levels of politically relevant resources, voting reforms bring well-off citizens to the polls repeatedly. The reason for this effect is straightforward. Sometimes, even the most engaged and interested citizens will fail to cast their vote on election day because they are sick, the weather is bad, they have missed a registration deadline, they have moved, or they are called out of town unexpectedly on business. Electoral reforms therefore increase the propensity of likely voters to consistently turnout by smoothing over the idiosyncrasies that cause engaged citizens to sometimes miss casting their votes in particular 
elections. Put simply, electoral reforms have a greater effect on retention than on stimulation.

The net effect of this process is that, over time, electoral reforms will likely increase the rate of turnout relative to the situation where the reforms were not in place. But it will achieve this increase by retaining those citizens who have a high propensity to vote, not by stimulating new-presumably less engaged-citizens to join the ranks of the voting public. As Southwell and Burchett (2000) put it, voting reforms bring the "cream of the crop" to the polls. Thus, electoral reforms do not change the nature of the electorate. Rather, they give us "more of the same" - they exacerbate, rather than ease, existing socioeconomic biases in the composition of the voting public.

\section{THE EVIDENCE}

Such a conclusion might be somewhat surprising to those who follow the partisan debate concerning electoral reform, but the evidence is clear. A large number of empirical studies of reforms designed to make the actual casting of the vote easier have converged on a common conclusion. Although these reforms do not create partisan biases in the electorate, they reinforce the demographic compositional bias of the electorate and may even heighten that bias.

Ideally, to observe the effects of voting reform on the composition of the electorate, we should examine over time individual-level data to see if these reforms have a greater effect on stimulation or on retention, which could not be seen in the aggregate results. Such data allow us to assess how particular electoral reforms change the ordinary patterns of the churning of the electorate.

Berinsky, Burns, and Traugott (2001) conducted one such investigation, studying the effects of VBM in Oregon. The authors found that VBM did increase the turnout in that state, but it did so primarily through retention. Specifically, they found that VBM was not very effective at pulling resistant registered nonvoters into the electorate, but it did a very good job of retaining existing voters. More important for present purposes, they found that VBM had dissimilar effects for different groups in the electorate. They found that VBM stimulated those individuals belonging to groups who were already likely to 
participate in elections - older voters, those who are well educated, and those with substantial amounts of campaign interest. As they conclude:

VBM stabilizes the electorate in a way that increases turnout over the long run. It does this not so much by mobilizing new voters into the electorate, but rather by retaining political participants over a series of elections. . . Moreover, the mobilization process works more effectively for the resource rich than the resource poor. ... In the end, the voters who move in and stay in the electorate look much like the existing voters in the system. By reducing many of the direct costs of electoral participation, VBM allows the habitual behavior of voters and nonvoters to take center stage. Those we would expect to vote-the resource rich-are more likely to sustain their vote over the long haul. And those we would expect to abstain-the resource poor-are more likely to stay out of the electorate over the long haul. (p. 193)

Though panel data may be the best way to examine the dynamic composition of the electorate, such studies are rare due to the cost of acquiring validated vote data. However, studies using cross-sectional data have come to conclusions similar to those of Berinsky et al. (2001). It is possible to look at cross-sectional data to see the residuals of the effects of voting reform. Specifically, by comparing the characteristics of those who take advantage of novel forms of voting and those who do not, we can estimate the effects of electoral reforms in a single election. Thus, although we cannot distinguish the effects of retention from those of stimulation, we can see if, as Berinsky et al. argue, it is the resource rich who are likely to take advantage of the easier forms of voting. The evidence from such studies is consistent and unambiguous: Voting reforms do not ameliorate the resourcebased biases of the electorate. In all cases, these reforms reinforce or increase such biases. I review this evidence here with respect to four specific reforms designed to make the act of voting easier: VBM, early voting, liberal absentee voting, and Internet voting.

\section{VBM SYSTEMS}

Like Berinsky et al. (2001), Southwell and Burchett (1997, 2000) examined the effects of VBM in Oregon. Using an RDD survey of voters at the time of the 1996 special election, they divided their respon- 
dents into three broad groups: (a) traditional voters, those who voted in the 1992 polling-place election, had no problems getting to the polls, and voted frequently in the past; (b) "VBM voters," voters who voted in the 1996 vote-by-mail election but did not vote in 1992, had trouble getting to the polls, or voted infrequently in the past; and (c) nonvoters, those citizens who did not vote in the 1996 vote-by-mail election. Southwell and Burchett $(1997,2000)$ found that "VBM voters" were slightly older, more urban, and less partisan than were the traditional voters. Nevertheless, these two groups were more similar to each other than they were to the nonvoters. Both the traditional voters and the VBM voters were better educated, more politically knowledgeable, and cared more about the outcome of the election than nonvoters. ${ }^{14}$ The authors therefore concluded that VBM does not improve the demographic representativeness of the electorate. Karp and Banducci (2000) came to similar conclusions with very different data. Using aggregate precinct-level turnout data from three Oregon counties matched with data from the 1990 census, they found that VBM increased turnout by White, educated, older, high-income voters. Vote-by-mail procedures did not increase turnout by minority or rural voters. Finally, Magleby (1987) examined VBM elections in California, Oregon, and Washington in the early 1980s using aggregate data and concluded that in most mail-ballot elections, the mail voters closely resembled municipal polling place electors. ${ }^{15}$

\section{EARLY VOTING}

Stein has studied the impact of early voting procedures in Texas (Stein, 1998; Stein \& Garcia-Monet, 1997). Analysis of two exit polls with early voters and election-day voters suggests that there are no demographic differences in the two populations. Thus, early voting produces an electorate that is no more representative of the full population than traditional election-day voting methods. Neely and Richardson (2001) came to similar conclusions regarding the effects of early voting using a 1996 telephone survey of registered voters in Knox County, Tennessee. They found that early voters tended to be more politically engaged than the rest of the electorate. That is, early voters were partisans and those citizens who follow elections closely. However, although early voting may have increased the 
aggregate level of political engagement of the voting population, it did not increase the demographic representativeness of the electorate. Multivariate analysis found no significant demographic differences between early and election-day voters, though bivariate analysis indicated that wealthy voters used early voting at a higher rate than other income groups. Neely and Richardson concluded that early voting simply allows those who would have voted on Election Day to vote at a more convenient time.

\section{ABSENTEE VOTING}

Karp and Banducci (2001) investigated whether liberal absentee voting laws expand the electorate using a national sample (42 states) of National Election Study data pooled from five successive elections. The authors found that older, more educated, politically active voters are more likely to vote absentee than other voters. They also found that more liberal absentee laws increase participation among two low-voting groups, students and the disabled, but do not increase voting rates among minorities or independents. States with liberal absentee laws had higher rates of absentee voting than states that did not adopt such procedures, but they also had higher rates of in-person voting. Thus, the authors theorized that higher turnout in states with liberal absentee voting laws might be an effect of a general participatory political culture rather than the existence of particular absentee voting procedures. Karp and Banducci's results therefore indicate that liberal absentee laws do little, if anything, to ameliorate the inherent demographic biases of the electorate. In an individual-level analysis of CPS data, Oliver (1996) comes to the same conclusion as Karp and Banducci (2001): voters with higher incomes and more education are more likely than other voters to take advantage of absentee ballot laws (for a review that comes to similar findings, see Hansen, 2001).

\section{INTERNET VOTING}

Much of the potential impact of the Internet on voting is speculative. In future elections, some members of the U.S. military and Americans living abroad may be able to cast their ballot online. ${ }^{16}$ However, there is one prominent example of widespread Internet voting in a 
major U.S. election - the 2000 Arizona Democratic Primary. Though Democrats in Arizona had only used a primary system since 1984, in 2000 , a record number of votes were cast, indicating that Internet voting procedures may have increased turnout. Alvarez and Nagler (2001) used ecological inference of turnout in the primary and found that non-Whites, the unemployed, and rural residents were less likely than other voters to use Internet balloting (as were women and the elderly). They concluded "Internet voting is likely to exacerbate the current problem of class-bias in American elections if it is introduced any time in the near future" (p. 28). Gibson (2002) also examined the effect of Internet voting in that same Arizona election. Like Alvarez and Nagler (2001), she used county-level data and concluded that despite the increased turnout in the 2000 election, the Arizona electorate was no more representative of the full population than previous elections. Specifically, she found that Internet voting occurred at a significantly higher rate in counties with higher median income and higher percentage of White residents.

\section{SUMMARY OF RESEARCH}

All told, using a variety of methods and data sources to assess the effects of different voting reforms, a series of scholars have come to a single conclusion. Across both aggregate and individual-level data sets, using both panel and cross-sectional designs, and employing exit polls, validated vote records, and telephone surveys, the results are consistent. Individuals who utilize easy voting procedures tend to be more politically engaged and interested than those who do not take advantage of the opportunity (in the case of VBM, early voting, and absentee voting). Moreover, individuals who make use of less restrictive voting procedures are better educated (in the case of VBM and absentee voting) and have higher incomes (for all reforms). Thus, voting reforms do not correct the biases inherent in the electorate, and in some cases, reforms may even worsen these biases.

\section{WHAT CAN BE DONE?}

The electoral reforms of the past three decades have not, as some politicians feared, led to a change in the partisan composition of the 
electorate. However, for scholars and practitioners interested in increasing the demographic representation of the electorate, this review sounds a dismal note. Electoral reforms, on their own, cannot ameliorate the present socioeconomic biases in the composition of the voting public because the increase in turnout these reforms bring is the result of the retention of transient voters, not the stimulation of nonvoters.

Moreover, the problems identified here cannot be solved by moving the focus of reform to electoral registration. Some authors have argued that the socioeconomic bias in the composition of the electorate is the result of restrictive registration laws (Piven \& Cloward, 1989). But the empirical evidence does not support this view. Over the past 30 years, it has become easier for citizens in the United States to register to vote (see Highton [2004] for a comprehensive review of these changes). With passage of the National Voter Registration Act (NVRA) in 1993, most state barriers to voting were removed. This liberalization has not led to greater socioeconomic equality in the composition of the electorate, as Piven and Cloward (1989) predicted. Current Population Survey (CPS) data indicates that the proportion of registered voters remained steady from 1992 to $2000 .{ }^{17}$ Moreover, as the appendix demonstrates, voting reforms did little if anything to ease the socioeconomic gap between voters and nonvoters, regardless of registration status. These findings are consistent with the balance of academic work concerning the effects of registration reform. Prior to the passage of the NVRA, several studies found that liberalizing voter registration laws might increase turnout but would have almost no impact on the socioeconomic composition of the electorate (Mitchell \& Wlezien, 1995; Wolfinger \& Rosenstone, 1980). ${ }^{18}$ Studies conducted since the passage of the NVRA yield similar findings. For instance, Knack and White (2000) find that the implementation of election-day registration procedures does not enhance the participation of low income and low education citizens. ${ }^{19}$ Reviewing the literature on the effects of registration laws on turnout, Highton (2004) concludes "There is now little room for enhancing turnout further by making registration easier" (p. 512).$^{20}$ In sum, the problem is not expanding the size of the potential electorate; the problem is in turning those potential voters to actual voters. ${ }^{21}$ Focusing on the direct costs of 
voting — both in registration and the act of casting a ballot—will not get us very far toward a goal of truly representative electorate.

However, a positive agenda can emerge from these results. The failure of electoral reforms to produce a more representative electorate casts doubt on the possibility of achieving full equality of political voice through institutional reform. Perhaps, then, institutional reform is not the proper response to the problem. There is another solutionone that involves reframing the puzzle of participation. Research on turnout has consistently shown that it is political interest and engagement that drives citizens to the polls and keeps them voting from election to election (Rosenstone \& Hansen, 1993; Verba, Schlozman, \& Brady, 1995). The studies reviewed here underscore this point. Politically engaged citizens are the ones who take advantage of liberal voting rules. Those lacking political interest remain nonvoters. The problem, from the point of achieving a demographically representative electorate, is that political engagement currently follows, rather than crosses, demographic divisions in the electorate. It is wealthier, more educated citizens who tend to be more engaged and informed about politics (Delli Carpini \& Keeter, 1996). These citizens possess the politically relevant resources that enable them to make meaningful links between their personal interests and values on one hand and controversies in the political world on the other. The costs of making these links are the real costs of political participation (see Berinsky, 2004). Thus, to expand the size and the diversity of the electorate, we should not just make it easier to vote through institutional reform-which, through the process of retention, produces a larger electorate, but one that is demographically similar to that found in elections conducted using traditional methods of casting ballots. We must also expand the scope of the politically engaged citizenry. Put another way, instead of making it incrementally easier for citizens to participate in politics, we should make people want to participate. This is a more difficult and less straightforward task than the implementation of electoral reforms. Perhaps political activists could present political grievances 
in ways that engage new groups of citizens, or elites could reframe issues in ways that speak more directly to the concerns of the disadvantaged (Schattschneider, 1960). Similarly, political leaders and political party leaders could expand efforts at mobilization in ways that more directly appeal to the political interests of ordinary citizens (Rosenstone \& Hansen, 1993). Defining a specific course of reform is beyond the scope of this article, but refocusing political reforms to address these concerns could be an important step in reforming the electoral process.

What is most important for future research is that we adopt a more catholic conception of the costs of political participation. A focus on the tangible costs of the act of voting has dominated the academic and popular discussion of voting reform for more than 30 years. Speaking of the potential of online voting, Jesse Gordin sums up the conventional wisdom well when he argues, "People always wonder why do so few people vote? Well, it's pretty obvious. Because it's hard" (Althoff, 2004, p. 26). The act of voting is indeed hard, but it is hard in ways different from those identified by political commentators. Rather than focus on the concrete costs of voting, we must focus on the less perceptible costs of becoming engaged with the political world. The true costs of participation lie not just in the expression of opinion but also in the formation of political opinions. Existing electoral reforms do nothing to minimize the cognitive costs associated with voting. Thus, reducing the direct costs of opinion expression by making voting easier will not, in and of itself, necessarily give equal voice to all groups in society. Certainly, making the act of participation as simple as possible is a worthy goal, but institutional reforms have taken us as far as they can toward a democratic electorate. To remedy the deficiencies of the American political system and increase turnout among habitual nonvoters, we must focus reform efforts on increasing the engagement of the electorate with the political world, thereby lowering the cognitive costs associated with political participation. 
486 AMERICAN POLITICS RESEARCH / JULY 2005

APPENDIX

Socioeconomic Characteristics of the Electorate (in percentages)

\begin{tabular}{|c|c|c|c|}
\hline Quartile & Not Registered & Registered, Did Not Vote & Voted \\
\hline \multicolumn{4}{|l|}{1992} \\
\hline \multicolumn{4}{|l|}{ Income level } \\
\hline First quartile & 36.3 & 37.8 & 18.4 \\
\hline Second quartile & 29.1 & 26.6 & 24.0 \\
\hline Third quartile & 21.7 & 20.5 & 27.7 \\
\hline Fourth quartile & 12.9 & 15.2 & 29.9 \\
\hline \multicolumn{4}{|l|}{ Education } \\
\hline Less than high school & 30.9 & 27.6 & 12.3 \\
\hline High school graduate & 43.4 & 38.5 & 33.0 \\
\hline Some college & 24.4 & 31.3 & 45.7 \\
\hline College graduate & 1.4 & 2.7 & 9.0 \\
\hline \multicolumn{4}{|l|}{1996} \\
\hline \multicolumn{4}{|l|}{ Income level } \\
\hline First quartile & 36.5 & 32.3 & 19.8 \\
\hline Second quartile & 26.4 & 24.9 & 21.5 \\
\hline Third quartile & 24.5 & 25.2 & 29.0 \\
\hline Fourth quartile & 12.5 & 17.7 & 29.7 \\
\hline \multicolumn{4}{|l|}{ Education } \\
\hline Less than high school & 28.2 & 20.2 & 10.8 \\
\hline High school graduate & 41.6 & 37.7 & 30.5 \\
\hline Some college & 28.4 & 38.5 & 48.7 \\
\hline College graduate & 1.7 & 3.7 & 10.1 \\
\hline \multicolumn{4}{|l|}{2000} \\
\hline \multicolumn{4}{|l|}{ Income level } \\
\hline First quartile & 38.0 & 36.1 & 20.4 \\
\hline Second quartile & 33.4 & 31.1 & 29.2 \\
\hline Third quartile & 15.7 & 17.1 & 21.8 \\
\hline Fourth quartile & 13.0 & 15.6 & 28.7 \\
\hline \multicolumn{4}{|l|}{ Education } \\
\hline Less than high school & 26.1 & 20.0 & 9.2 \\
\hline High school graduate & 41.4 & 38.0 & 30.0 \\
\hline Some college & 30.4 & 38.8 & 50.5 \\
\hline College graduate & 2.1 & 3.2 & 10.7 \\
\hline
\end{tabular}

SOURCE: Current Population Survey: Voter Supplement File, November 1992, November 1996, November 2000.

NOTE: The column entries are the percentage of a particular group (not registered/registered, did not vote/voted) in a given socioeconomic category. 


\section{NOTES}

1. The empirical record concerning the representativeness of the attitudes of political participants is somewhat mixed. Wolfinger and Rosenstone (1980) use data from 1972 to find that voters and nonvoters do not differ significantly in their policy preferences. Using data collected almost two decades later, Verba, Schlozman, Brady, and Nie (1993) come to a similar conclusion. Other scholars, however, have found that voters and nonvoters do not see eye-to-eye on matters of public policy. Berinsky (2002) finds that nonvoters are more liberal on social welfare policy questions than are voters. Similarly, Bennett and Resnick (1990) find that nonvoters are "slightly more in favor of an increased government role in the domestic arena" (p. 789).

2. Of course, I am not the first to make this point (see Alvarez \& Nagler, 2001; Leighley \& Nagler, 1992; Highton, 2004). What is novel about the argument presented here is the two-path conception of dynamic turnout discussed below.

3. For instance, the passage of the National Voter Registration Act (NVRA) did not increases turnout levels as proponents of the bill expected. The more interesting question, from the perspective of this review, is whether this reform changed the composition of the electorate.

4. For my analysis, I chose to examine those reforms designed specifically to ease the direct costs of casting a ballot. Although I focus on particular reforms here, the critique advanced here can be applied to other reforms designed to ease the costs of the act of voting, including policies designed to make voter registration easier (see below). I do not speak to other balloting reforms such as the voting equipment reforms addressed in the Help America Vote Act of 2002 (HAVA) or provisional ballots (those ballots cast in a polling place by voters whose names do not appear on the precinct roster).

5. In some jurisdictions, voters can request to become "permanent absentee voters" so a ballot will always be mailed to their homes.

6. In 2004, for instance, residents of Texas can cast early votes beginning 17 days before the election and ending 4 days before Election Day (Texas Secretary of State Website, http:// www.sos.state.tx.us/elections/voter/earlyvoting.shtml, accessed May 25, 2004).

7. See also Denardo (1980) and Nagel and McNulty (1996).

8. Campbell (1966), it should be noted, accounted for the types of churning of the electorate considered here.

9. Using data from the 1972-1976 National Elections Study Panel, we can observe the voting behavior of 1,216 respondents across the two presidential elections. Among these respondents, in both elections, reported turnout was virtually unchanged, holding steady at almost $80 \%$ in both elections (78\% in 1972 and 79\% in 1976). However, among the sample, 16\% of the respondents voted in one election, but not the other, whereas $70 \%$ voted in both elections, and $14 \%$ never voted. Panel data from the 1992-1996 election cycles demonstrates a similar pattern. Among the 545 respondents who reported their voting behavior in both 1992 and 1996, turnout was $81 \%$ in 1992 and $78 \%$ in 1996. In this sample, $71 \%$ of respondents voted in both elections, $17 \%$ voted in one election but not the other, and $12 \%$ never voted. Although this level of churning is not as pronounced as the turnover found in elections for lower office, the results demonstrate that even in the most salient and highest profile elections, registered voters move in and out of the electorate from election to election. More important, in both of these cases, the population of transient voters is larger than the population of nonvoters. It should also be noted that these results are not dependent on the use of self-reported data, which research has shown to be subject to the over-reporting of levels of turnout (Presser \& Traugott, 1992; Silver, Anderson, \& Abramson, 1986). The 1972-1976 Panel contains validated voting data in addition to the selfreport data. Among the 1,302 panel respondents whose voting behavior could be validated, $85 \%$ 
voted in 1972 and $88 \%$ voted in 1976, again demonstrating a high degree of stability in aggregate turnout. However, of these respondents, 77\% voted in both elections, 5\% never voted, and $18 \%$ voted in one election, but not the other. Thus, the pattern for the validated data is the same as for the reported data, thereby underscoring the robustness of these results.

10. See Brody and Sniderman (1977) and Gerber, Green, and Shacher (2003) for a discussion of habitual patterns of voting behavior.

11. In sum, the individual level shifts in voting behavior that affect aggregate turnout are the result of two distinct processes. Registered nonvoters can be brought into the electorate, as Campbell (1966) envisioned (stimulation), but transient voters can also be encouraged to maintain their voting participation and stay in the electorate (retention).

12. Understanding this second path to increasing the electorate is important, so I will spend some time explicating the process of stimulation - the activation of nonvoters - and retentionensuring that transient voters keep coming to the polls-using an analogy from population dynamics. Consider two groups of the same initial size. If the birth rates and death rates are the same for both populations, the two groups will be the same size one year later. However, if the birth rate of the second group is higher than that of the first, the size of the second group will increase relative to the first group after one year. This condition is akin to increasing the population of voters through an increase in the rate of stimulating nonvoters to join the electorate. Similarly, if the death rate of the second group is smaller than that of the first, the size of the second group will also increase relative to that of the first group. This condition is akin to increasing the size of the voting population by keeping transient voters in the electorate from election to election. That is, this process is akin to retention. The same point can be made about absolute turnout levels for a single group. If birth and death rates are equal for a given group, then the size of the population will not change after one year, although the composition of the living will. This is akin to a churning electorate where total aggregate turnout is unchanged even though the population of voters does change from election to election. However, if the death rate decreases, then there will be population growth as births outnumber deaths. This is akin to increasing aggregate turnout by increasing retention.

13. Following the lead of Wolfinger and Rosenstone (1980), most academics argue that such changes will not change the partisan balance of the electorate. Recent work, however, has found that increasing turnout in the U.S. might change the outcome of elections (see Citrin, Schickler, and Sides [2003] regarding national elections and Hajnal and Trounstine [in press] regarding the potentially serious consequences for local elections of class and race-based imbalances in turnout). Politicians, on the other hand, are less confident about the nature of partisan effects. For example, Republican Phil Gram said passage of HR2, the precursor to the NVRA, would "tilt the political system" to the benefit of the Democratic party (quoted in Calvert and Gilchrist [1993]).

14. These conclusions are drawn from bivariate analysis in the 1997 piece. These differences hold up in the multivariate context as well. Although the authors did not directly compare the three groups in such a context, logit analysis in their 2000 piece indicated that although votingby-mail (VBM) voters and traditional voters did not differ on education and political knowledge, VBM voters and registered nonvoters differed on those two quantities.

15. In drawing inferences of individual-level behavior from aggregate data, these studies suffer from potential ecological inference problems (Robinson, 1950; for modern treatments, see Achen and Shively [1995] and King [1997]). However, the convergence of the findings of the VBM studies using aggregate data and those using individual-level data suggests that this flaw is not fatal.

16. Online voting for overseas military personnel was planned for 2004 through the Pentagon-run Secure Electronic Registration and Voting Experiment. This program was canceled in February, 2004, due to security concerns. 
17. The registration rate in the United States was $78.3 \%$ in $1992,77.2 \%$ in 1996 , and $78.4 \%$ in 2000 according to my analysis of the Current Population Survey (CPS) data.

18. In a slightly different vein, but one that supports the findings of this article, Wolfinger and Highton (1998) find that the adoption of a motor-voter program in Colorado increased turnout overall, but these gains came primarily among those with high school degrees and some college education. The gains were lowest among those with less than a high school education.

19. Specifically, using CPS data from 1990 and 1994, they find that states that adopted EDR improved equality of representation by age and mobility status. However, they found no difference on education and income (once the previous level of state turnout was introduced as a control variable). They conclude that "those supporting [registration] reforms in the hopes of improving participation among the poor and less educated (groups, reasonably, albeit over-simplistically, associated with liberal and Democratic party causes) may be disappointed by our findings.... Our results do not substantiate the claim that pre-NVRA administrative barriers to registering acted as 'de facto income and literacy test' " (2000, p. 41). Similarly, in a study of voting behavior in states with minimal restrictions on registration, Highton (1997) finds little amelioration of the socioeconomic skew of the electorate compare to states with more restrictive laws. He concludes that registration laws, "do not appear to be the main reason for the socioeconomic skew of American voters" (p. 573). Hanmer's (2004) study of EDR and motor-voter registration comes to a similar conclusion. He finds that while the least educated citizens appear to gain the most from easier registration procedures, the overall differences across education levels are quite small. Hanmer concludes that these registration reforms do little to reduce inequality in turnout. It should be noted that the evidence is not unanimous on this point; other studies have addressed the effects of registration reform and find evidence that is somewhat mixed. Alvarez, Ansolabehere, and Wilson (2002) analyze CPS data from 2000 to address the counterfactual question of how the composition of the electorate would change if EDR was adopted in all states. They conclude that turnout would increase across the board but EDR would diminish the education imbalance in the composition of the electorate (though their analyses also indicate that the income stratification of the election would persist).

20. Traugott (2004) reviews the literature on the effects of liberalized registration laws and finds that these reforms have no appreciable effect on the socioeconomic composition of the electorate.

21. The same is true of the series of electoral reforms mandated by HAVA, such as voting technology improvements and the creation of centralized voter registration lists. These reforms are important in that they can help ensure that votes cast in particular elections record the intended votes of citizens. But literature reviewed here suggests that even a compendium of improved electoral institutions will not significantly change the composition of the electorate.

\section{REFERENCES}

Achen, C. H., \& Shively, W. P. (1995). Cross-level inference. Chicago: University of Chicago Press.

Alvarez, R. M. L., Ansolabehere, S., \& Wilson, C. H. (2002). Election day voter registration in the United States: How one-step voting can change the composition of the American electorate. Caltech/MIT Voting Technology Project Working Paper.

Alvarez, R. M. L., \& Hall, T. E. (2004). Point, click, and vote: The future of internet voting. Washington, DC: Brookings Institution. 
Alvarez, R. M., \& Nagler, J. (2001). The likely consequences of Internet voting for political representation. Loyola Law Review, 34, 1115-1153.

Althoff, S. (2004, March 7). Point, click, elect. Boston Globe Magazine, p. 26.

Bennett, S. E., \& Resnick, D. (1990). The implications of nonvoting for democracy in the United States. American Journal of Political Science, 34, 771-802.

Berinsky, A. J. (2002). Silent voices: Social welfare policy opinions and political equality in America. American Journal of Political Science, 46, 276-287.

Berinsky, A. J. (2004). Silent voices: Opinion polls and political participation in America. Princeton, NJ: Princeton University Press.

Berinsky, A. J., N. Burns, \& Traugott, M. W. (2001). Who votes by mail? A dynamic model of the individual-level consequences of vote-by-mail systems. Public Opinion Quarterly, 65, 178197.

Brody, R. A., \& Sniderman, P. M. (1977). From life space to polling place: The relevance of personal concerns for voting behavior. British Journal of Political Science, 7, 337-360.

Calvert, J. W., \& Gilchrist, J. (1993). Suppose they held an election and almost everybody came! PS: Political Science and Politics, 26, 695-700.

Campbell, A. (1966). Surge and decline: A study of electoral change. In A. Campbell, P. E. Converse, W. Miller, \& D. Stokes (Eds.), Elections and the political order (pp. 40-62). New York: Wiley.

Citrin, J., Schickler, E., \& Sides, J. (2003). What if everyone voted? Simulating the impact of increased turnout in senate elections. American Journal of Political Science, 47, 75-90.

Delli Carpini, M. X., \& Keeter, S. (1996). What Americans know about politics and why it matters. New Haven, CT: Yale University Press.

DeNardo, J. (1980). Turnout and the vote: The joke's on the Democrats. American Political Science Review, 74, 406-420.

Gerber, A. S., Green, D. P., \& Shachar, R. (2003). Voting may be habit-forming: Evidence from a randomized field experiment. American Journal of Political Science, 47, 540-550.

Gibson, R. (2002). Elections online: Assessing internet voting in light of the Arizona democratic primary. Political Science Quarterly, 116, 561-583.

Hajnal, Z., \& Trounstine, J. (in press). Where turnout matters: The consequences of uneven turnout in city politics. Journal of Politics.

Hanmer, M. J. (2004). From selection to election and beyond: Understanding the causes and consequences of electoral reform in America. Unpublished doctoral dissertation, University of Michigan.

Hansen, J. M. (2001). Early voting, unrestricted absentee voting, and voting by mail. Unpublished report of the Task Force on the Federal Election System.

Highton, B. (1997). Easy registration and voter turnout. Journal of Politics, 59, 565-575.

Highton, B. (2004). Registration and voting in the United States. Perspectives on Politics, 2, 507515.

Karp, J. A., \& Banducci, S. A. (2000). Going postal: How all-mail elections influence turnout. Political Behavior, 22, 223-239.

Karp, J. A., \& Banducci, S. A. (2001). Absentee voting, mobilization, and participation. American Politics Research, 29, 183-195.

King, G. (1997). A solution to the ecological inference problem: Reconstructing individual behavior from aggregate data. Princeton, NJ: Princeton University Press.

Knack, S., \& White, J. (2000). Election-day registration and turnout inequality. Political Behavior, 22, 29-44.

Leighley, J. E., \& Nagler, J. (1992). Socioeconomic class bias in turnout, 1964-1988: The voters remain the same. American Political Science Review, 86, 725-736. 
Magleby, D. (1987). Participation in mail ballot elections. Western Political Quarterly, 40, 7991.

Mitchell, G. E., \& Wlezien, C. (1995). The impact of legal constraints on voter registration, turnout, and the composition of the American Electorate. Political Behavior, 17, 179-202.

Nagel, J. H., \& McNulty, J. E. (1996). Partisan effects of voter turnout in senatorial and gubernatorial elections. American Political Science Review, 90, 780-793.

Neely, G. W., \& Richardson, L. E., Jr. (2001). Who is early voting? An individual level examination. The Social Science Journal, 38, 381-392.

Oliver, J. E. (1996). The effects of eligibility restrictions and party activity on absentee voting and overall turnout. American Journal of Political Science, 40, 498-513.

Piven, F. F., \& Cloward, R. A. (1989). Government statistics and conflicting expectations of nonvoting. PS: Political Science and Politics, 22, 578-589.

Presser, S., \& Traugott, M. (1992). Little white lies and social science models: Correlated response errors in a panel study of voting. Public Opinion Quarterly, 56, 77-86.

Robinson, W. S. (1950). Ecological correlations and the behavior of individuals. American Sociological Review, 15, 351-357.

Rosenstone, S. J., \& Hansen, J. M. (1993). Mobilization, participation, and democracy in America. New York: MacMillian.

Schattschneider, E. E. (1960). The semisovereign people: A realist's view of democracy in America. Fort Worth, TX: Harcourt Brace Jovanovich College Publishers.

Sigelman, L., \& Jewell, M. E. (1986). From core to periphery: A note on the imagery of concentric electorates. Journal of Politics, 48, 440-449.

Silver, B. D., Anderson, B. A., \& Abramson, P. R. (1986). Who overreports voting? The American Political Science Review, 80, 613-624.

Southwell, P., \& Burchett, J. (1997). Survey of vote-by-mail senate election in the state of Oregon. PS: Political Science and Politics, 30, 53-57.

Southwell, P., \& Burchett, J. (2000). Does changing the rules change the players? The effect of all-mail elections on the composition of the electorate. Social Science Quarterly, 81, 837 845 .

Stein, R. M. (1998). Early voting. Public Opinion Quarterly, 62, 57-69.

Stein, R. M., \& Garcia-Monet, P. A. (1997). Voting early, but not often. Social Science Quarterly, $78,657-671$

Traugott, M. W. (2004). Why electoral reform has failed: If you build it, will they come? In A. N. Crigler, M. R. Just, \& E. McCaffery (Eds.), Rethinking the vote: The politics and prospects of American election reform. New York: Oxford University Press.

Wolfinger, R., \& Highton, B. (1998). Estimating the effects of the national voter registration act of 1993. Political Behavior, 20, 79-104.

Wolfinger, R., \& Rosenstone, S. J. (1980). Who votes? New Haven, CT: Yale University Press.

Verba, S., Schlozman, K. L., \& Brady, H. E. (1995). Voice and equality. Civic voluntarism in American politics.Cambridge, MA: Harvard University Press.

Verba, S., Schlozman, K. L., Brady, H. E., \& Nie, N. H. (1993). Citizen activity: Who participates? What do they say? American Political Science Review, 8, 303-318.

Adam J. Berinsky is an associate professor of Political Science at MIT. He has published articles in the American Journal of Political Science, Journal of Politics, Political Psychology, and Public Opinion Quarterly. He is the author of Silent Voices: Public Opinion and Political Representation in America (Princeton University Press, 2004). 